\title{
Serum Prostacyclin Binding Defects in Thrombotic Thrombocytopenic Purpura
}

Kenneth K. Wu, Elizabeth R. Hall, Ennio C. Rossi, and Audrey C. Papp

Department of Internal Medicine, Division of Hematology, University of Texas Health Science Center at Houston, Houston, Texas

77030; Northwestern University School of Medicine, Chicago, Illinois 60611

\section{Abstract}

To understand the pathophysiologic significance of abnormal serum prostacyclin $\left(\mathbf{P G I}_{2}\right)$ binding activities in thrombotic thrombocytopenic purpura (TTP), we evaluated the $\mathbf{P G I} \mathbf{I}_{2}$ binding characteristics in three chronic TTP sera and 19 normal sera. $\mathbf{P G I}_{2}$ binding by serum was rapid and reversible. The binding activity in TTP sera (22.1 \pm SD, 4.4\%) was significantly lower than that of normal sera $(42.2 \pm 6.2 \%)$. Moreover, the antiaggregating activity and 6-keto-prostaglandin $F_{1 a}\left(6 \mathrm{KPGF}_{1 \alpha}\right)$ content in the gel filtrates representing the binding peak was proportionally lower in a TTP serum than normal serum. Although normal and TTP sera bound $\left[{ }^{14} \mathrm{C}\right]$ arachidonate with similar activity, and neither bound $\left[^{3} \mathrm{H}\right] 6 \mathrm{KPGF}_{1 \alpha}$, there was a difference in prostaglandin $E_{1}\left(P G E_{1}\right)$ binding. Binding of $\left[{ }^{3} \mathbf{H}_{\text {PGE }}\right.$ was subnormal in two TTP sera (W.J. and T.G.) and normal in the third (H.S.). Normal serum corrected the binding defects of TTP serum. Interestingly, the mixture of two TTP sera (W.J. and H.S.) mutually corrected their PGI $_{2}$ binding defects. In addition, although in vivo plasma transfusions improved the $\mathbf{P G I}_{2}$ binding activity of W.J. and H.S., there existed a striking difference in the nature of their response. These observations indicate that there are at least two types of PGI $\mathbf{P}_{2}$ binding defects in TTP.

Our data indicate that TTP is associated with diminished serum binding of $\mathbf{P G I} \mathbf{I}_{2}$. This defect may reduce the availability of $\mathbf{P G I}_{2}$ to damaged vascular sites and decrease an important modulator of platelet thrombus formation at times of severe vascular insult.

\section{Introduction}

Thrombotic thrombocytopenic purpura (TTP) ${ }^{1}$ is a clinical syndrome characterized by microangiopathic hemolytic anemia, thrombocytopenia, fever, and neurologic and renal abnormalities (1). The pathophysiologic basis for these clinical manifestations is thought to be due to the deposition of platelet and fibrin thrombi in the microcirculation. Although the pathogenetic mechanisms of this disorder are not entirely clear, recent studies have disclosed several possible mechanisms such as endothelial cell damage by immune complexes and platelet

Address correspondence to Dr. Wu, Division of Hematology.

Received for publication 10 March 1982 and in revised form 10 September 1984.

1. Abbreviations used in this paper: 6KPGF $1 \alpha$, 6-keto-prostaglandin $\mathrm{F}_{1 \alpha}$; PPP, platelet-poor plasma; PRP, platelet-rich plasma; PAGE, polyacrylamide gel electrophoresis; $\mathbf{P G I}_{2}$, prostacyclin; $\mathrm{PGE}_{1}$, prostaglandin $\mathrm{E}_{1}$; TTP, thrombotic thrombocytopenic purpura.

J. Clin. Invest.

(c) The American Society for Clinical Investigation, Inc. 0021-9738/85/01/0168/07 \$1.00

Volume 75 , January $1985,168-174$ aggregate formation by platelet aggregating factor (2) and the presence of abnormal Factor VIII:von Willebrand Factor multimers (3). We have recently detected accelerated serum prostacyclin $\left(\mathrm{PGI}_{2}\right)$ degradation (nonenzymatic hydrolysis) in a patient with chronic TTP (4). Detailed clinical and laboratory correlates suggest that reduced $\mathbf{P G I}_{2}$ bioavailability may play an important role in the pathogenesis of TTP. Subsequently, we measured serum $\mathrm{PGI}_{2}$ binding activity by gel filtration and found a significantly lower binding activity in this patient (5). To understand the pathophysiologic significance of abnormal serum $\mathrm{PGI}_{2}$ binding in TTP, we have investigated the binding defects in three patients with chronic or relapsing TTP.

\section{Methods}

Serum. Serial serum samples were obtained from three patients (W.J., a 42-yr-old male; T.G., a 33-yr-old female; and H.S., a 32-yr-old female) who had the typical clinical pentad of fever, microangiopathic hemolytic anemia, thrombocytopenia, neurological symptoms, and renal dysfunctions. None of the patients had underlying diseases. Patient W.J. (4, 5) and H.S. (6) have been reported. All three patients initially recovered after plasma exchange therapy but relapsed subsequently. Patients W.J. and T.G. relapsed at regular intervals of 3-4 wk and have required plasma therapy for 27 and 30 mo, respectively. Patient H.S. relapsed twice but responded to plasma exchange and/or infusion on each occasion. Serum samples were prepared from the patients and 19 normal subjects by incubating venous blood at $37^{\circ} \mathrm{C}$ for $2 \mathrm{~h}$, centrifuging samples at $1,500 \mathrm{~g}$ for $20 \mathrm{~min}$ and storing samples at $-70^{\circ} \mathrm{C}$ until use. Fresh and frozen samples gave identical binding and degradation results.

Materials. $\left[{ }^{3} \mathrm{H}\right] \mathrm{PGI}_{2}$ methyl ester $(12 \mathrm{Ci} / \mathrm{mmol}),\left[{ }^{3} \mathrm{H}\right] 6-k e t o-\mathrm{PGF}_{1 \alpha}$ $\left(6 \mathrm{KPGF}_{1 \alpha}\right)(150 \mathrm{Ci} / \mathrm{mmol}),\left[{ }^{14} \mathrm{C}\right]$ arachidonic acid $(55.8 \mathrm{Ci} / \mathrm{mmol})$ and $\left[{ }^{3} \mathrm{H}\right]$ prostaglandin $\mathrm{E}_{1}\left(\mathrm{PGE}_{1}\right)(59.5 \mathrm{Ci} / \mathrm{mmol})$ were obtained from New England Nuclear, Boston, MA. $\left[{ }^{3} \mathrm{H}\right] \mathrm{PGI}_{2}$ methyl ester was reduced to $\left[{ }^{3} \mathrm{H}_{\mathbf{P G I}} \mathbf{P}_{2}\right.$ sodium and purified by thin-layer chromatography (7). $\mathbf{P G I}_{2}$ sodium salt and $6 \mathrm{KPGF}_{1 \alpha}$ were generous gifts of the Upjohn Co., Kalamazoo, MI. Sephadex G-25 medium and Sephacryl S-200 were obtained from Pharmacia Fine Chemicals, Piscataway, NJ. Trypsin (type III) and $\alpha$-chymotrypsin (type II) were purchased from Sigma Chemical Co., St. Louis, MO. A series of human albumin preparations (i.e., Cohn fraction V, crystalline, and defatted albumin) were purchased from Research Plus, Bayonne, NJ. Crystalline and defatted human albumin preparations were also obtained from Sigma Chemical Co.

Serum $\mathrm{PGI}_{2}$ binding was evaluated by gel filtration (8). Sephadex G-25 medium gel was swollen in $0.05 \mathrm{M}$ Tris buffer, pH 7.4, and packed in a plastic column $(21.5 \times 0.8 \mathrm{~cm})$ that was washed with 3 bed vol of buffer. The flow rate was $\sim 1 \mathrm{ml} / \mathrm{min}$. $\left[{ }^{3} \mathrm{H}\right] \mathrm{PGI}_{2}$ was incubated with serum before gel filtration. An incubation time of 3 min and temperature of $22^{\circ} \mathrm{C}$ were deemed optimal based on our pilot experiments. After discarding an initial 3-ml vol, $0.35-\mathrm{ml}$ fractions were collected and the radioactivity of each fraction was determined in a Packard scintillation spectrometer (Packard Instrument Co., Inc., Downers Grove, IL). As the radioactivity recovered in all the fractions was $99-100 \%$ of the radioactivity added, the recovered radioactive counts were used as the basis for determining the percentage of binding. The percentage of total radioactivity eluted with the non-included serum proteins (peak I, Fig. 1) gave a measure of $\mathbf{P G I}_{2}$ binding. In the 


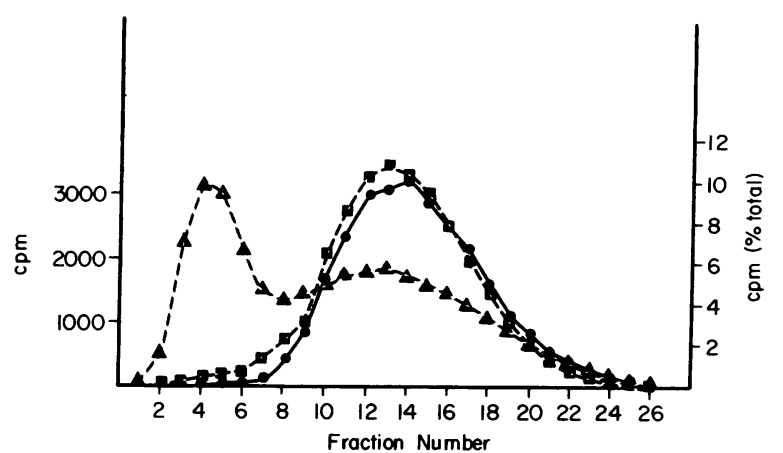

Figure 1. A representative gel filtration pattern of normal serum. $\left[{ }^{3} \mathrm{H}\right] \mathrm{PGI}_{2}$ or $\left[{ }^{3} \mathrm{H}\right] 6 \mathrm{KPGF}_{1 \alpha}(10 \mathrm{nM})$ was incubated in serum or 0.05 $\mathrm{M}$ Tris buffer (pH 7.4) at $22^{\circ} \mathrm{C}$ for $3 \mathrm{~min}$ and $0.35 \mathrm{ml}$ of the buffer, pH 7.4. Fractions were collected and the radioactivity and percentage of total added radioactivity were determined. Two peaks were noted with the $\mathrm{PGI}_{2}$-serum mixture $(\Delta-\Delta)$. Only a single peak was noted with the $6 \mathrm{KPGF}_{1 a}$-serum mixture $(\square-\square)$ and the $\mathrm{PGI}_{2}-$ buffer mixture $(\bullet-\bullet)$, both of which resembled the pattern obtained with a $6 \mathrm{KPGF}_{1 \alpha}$-buffer mixture.

dose-response experiments, increasing $\left[{ }^{3} \mathrm{H}\right] \mathrm{PGI}_{2}$ concentrations were used in the gel filtration. In all other experiments, unless otherwise specified, $10 \mathrm{nM}\left[{ }^{3} \mathrm{H}\right] \mathrm{PGI}_{2}$ was used. Serum binding of $\left[{ }^{3} \mathrm{H}\right] \mathrm{PGE}_{1}(10$ $\mathrm{nM}),\left[{ }^{3} \mathrm{H}\right] 6 \mathrm{KPGF}_{1 \alpha}(10 \mathrm{nM})$ and $\left[{ }^{14} \mathrm{C}\right]$ arachidonic acid $(46 \mathrm{nM})$ was measured by the same gel filtration technique.

Bioassay for $\mathrm{PGI}_{2}$ was based upon the inhibitory effect of $\mathrm{PGI}_{2}$ on ADP-induced platelet aggregation. Venous blood was drawn from normal donors and collected in plastic tubes containing $1 / 10 \mathrm{vol}$ of $3.8 \%$ sodium citrate. The blood sample was centrifuged at $200 \mathrm{~g}$ for 10 min to obtain platelet-rich plasma (PRP) and the remaining sample was centrifuged at $1,500 \mathrm{~g}$ for $15 \mathrm{~min}$ to prepare platelet-poor plasma (PPP). The platelet concentration in the PRP was adjusted to $3 \times 10^{8}$ / $\mathrm{ml}$ with autologous PPP. Platelet aggregation was measured by the turbidimetric method using a Chronolog aggregometer (9). ADP (1$10 \mu \mathrm{l})$ was added to $0.5 \mathrm{ml}$ PRP in a cuvette containing a stirring bar and the extent of increment in light transmission was measured in 3 min. In each experiment, the minimal ("threshold") concentration of ADP that caused maximal aggregation was determined and this concentration was used for the bioassay. Increasing concentrations of standard $\mathrm{PGI}_{2}$ sodium were incubated with PRP in the aggregometer for $15 \mathrm{~s}$ followed by the addition of ADP. A calibration curve was constructed in each experiment. The quantity of $\mathbf{P G I}_{2}$ in an unknown sample was obtained by relating the inhibition of platelet aggregation to the calibration curve.

Radioimmunoassay for $6 K P G F_{1 \alpha}$. Antiserum against $6 \mathrm{KPGF}_{1 \alpha}$ was obtained by repeated immunization of rabbits with $6 \mathrm{KPGF}_{1 \alpha}$ coupled to bovine serum albumin. The anti-6 $\mathrm{KPGF}_{1 \alpha}$ was used at a final dilution of $\left.1 / 8,000 .{ }^{3} \mathrm{H}\right] 6 \mathrm{KPGF}_{1 \alpha}$ was used as the labeled antigen. The antiserum showed little cross-reactivity with $\mathrm{PGF}_{2 \alpha}(4.2 \%), \mathrm{PGE}_{1}$ (1.3\%), thromboxane $\mathrm{B}_{2}(<0.03 \%)$, arachidonic acid $(<0.01 \%)$, PGF $_{1 \mathrm{ac}}$ $(5.7 \%)$ and 6-keto-PGE $(6.4 \%)$. The sensitivity of the assay was 10 $\mathrm{pg} /$ tube (i.e., $B / B O=90 \%$ ).

$\mathrm{PGI}_{2}$ content in gel filtrates. Unlabeled $\mathrm{PGI}_{2}$ sodium at various concentrations was incubated with $0.35 \mathrm{ml}$ serum at $22^{\circ} \mathrm{C}$ for $3 \mathrm{~min}$ and then applied to a Sephadex G-25 column. Fractions representing peaks I and II as identified by the $\left[{ }^{3} \mathrm{H}_{\mathrm{PGI}}\right.$ binding experiments were collected. $\mathbf{P G I}_{2}$ activity was measured by bioassay and $6 \mathrm{KPGF}_{1 \alpha}$ was measured by radioimmunoassay (see above).

Serum $\mathrm{PGI}_{2}$ degradation. $\mathbf{P G I}_{2}$ degradation was determined by a modification of a procedure described (4). In each experiment, a $\mathbf{P G I}_{2}$ concentration that inhibited 75-95\% of ADP-induced platelet aggregation was incubated with normal or patient serum at $37^{\circ} \mathrm{C}$. The $\mathrm{PGI}_{2}$ concentrations ranged from 10 to $20 \mathrm{nM}$. Aliquots $(50 \mu \mathrm{l})$ of the mixture were removed at $1,5,15$ min, etc., and the decline in $\mathbf{P G I}_{2}$ activity was measured as the decline in antiaggregatory activity. The half-life of $\mathbf{P G I}_{2}$ was determined as the time interval at which $50 \%$ of the added $\mathbf{P G I}_{2}$ activity had disappeared.

Ammonium sulfate precipitation of serum was used for the preliminary separation of the active binding component(s). Saturated $\left(\mathrm{NH}_{4}\right)_{2} \mathrm{SO}_{4}$ was added to serum until it had reached 30,60 , and $80 \%$ saturation, respectively. The supernatant was removed, concentrated, and dialyzed against phosphate-buffered saline. The binding percentage of the supernatant was determined by gel filtration as described above. The $60 \%\left(\mathrm{NH}_{4}\right)_{2} \mathrm{SO}_{4}$ supernatant (fraction $\mathrm{D}$ ) contained the active component and was used for further biochemical studies. The protein concentration was determined by the method of Lowry (10).

Chromatographies. DEAE chromatography was performed by applying fraction D to a DE-52 column (Whatman, Inc., Clifton, NJ) that had been equilibrated with $50 \mathrm{mM}$ sodium phosphate buffer, $\mathrm{pH}$ 7.0. The column was washed with buffer until the ultraviolet 280 absorbance stabilized and then eluted with buffer containing $1 \mathrm{M}$ $\mathrm{NaCl}$. Hydroxylapatite chromatography was performed by diluting fraction $D$ with an equal volume of $20 \mathrm{mM}$ sodium phosphate buffer, pH 7.4 and mixing the sample with $1 \mathrm{ml}$ of Bio-Gel HT (Bio-Rad Laboratories, Richmond, CA). The Bio-Gel HT material was removed by centrifugation and washed with $1 \mathrm{M}$ sodium phosphate buffer, $\mathrm{pH}$ 8.5 to remove bound proteins. Dye ligand chromatography was performed by applying $0.5 \mathrm{ml}$ serum to dye matrex columns (Amicon Corp., Danvers, MA). The columns were washed and then eluted with $20 \mathrm{mM}$ potassium phosphate buffer, $\mathrm{pH} 7.4$, containing $1.5 \mathrm{M} \mathrm{KCl}$. All fractions were dialyzed and concentrated on an Amicon PM 30 membrane before testing.

Electrophoresis. Preparative isoelectric focusing was used to identify proteins in fraction D. Fraction D was electrofocused for $18 \mathrm{~h}$ with 8 W constant power at $8-10^{\circ} \mathrm{C}$. A blot was made and stained. Then the gel bed was divided into fractions, the $\mathrm{pH}$ measured and the proteins removed by washing the gel in buffer. The fractions were titrated to pH 7.4 and concentrated by ultrafiltration on an Amicon PM 30 membrane.

SDS polyacrylamide gel electrophoresis (PAGE) was performed on 7.5\% polyacrylamide gels according to a modified method of Laemmli (11). All the reagents were obtained from Bio-Rad Laboratories, including the Tris/acetate/SDS buffer (Tris $24.84 \mathrm{~g} /$ liter, acetic acid $11.7 \mathrm{ml} /$ liter, SDS $1 \mathrm{~g}$ /liter, pH of buffer 6.4, pH of gel 6.1). Fraction $D$, whose protein content was standardized at $33 \mu \mathrm{g}$ for all samples, was pretreated with SDS and dithiothreitol (Sigma Chemical Co.) and then applied to the SDS-polyacrylamide gels. The protein bands were stained with Coomassie Brilliant Blue.

\section{Results}

$P G I_{2}$ binding characteristics of normal and TTP sera. Two peaks were noted when normal human serum preincubated with $\mathrm{PGI}_{2}$ was subjected to gel filtration (Fig. 1). Peak I, which coincided with the void volume represents $\mathrm{PGI}_{2}$ binding to a macromolecular serum component and peak II represents the standard $6 \mathrm{KPGF}_{1 \alpha}$ peak. The first peak was absent when $6 \mathrm{KPGF}_{1 \alpha}$ was added to serum, indicating that $6 \mathrm{KPGF}_{1 \alpha}$ does not bind to this serum component. The binding of $\mathrm{PGI}_{2}$ to the serum component was rapid (i.e., it had reached a maximum in $\leq 30 \mathrm{~s}$ ) and reversible. The reversibility of $\mathrm{PGI}_{2}$ binding was demonstrated by the displacement of $\left[{ }^{3} \mathrm{H}\right] \mathrm{PGI}_{2}$ by cold $\mathrm{PGI}_{2}$. Normal serum was incubated with $\left[{ }^{3} \mathrm{H}\right] \mathrm{PGI}_{2}(10 \mathrm{nM})$ for 3 min and divided into three aliquots. One aliquot was chromatographed immediately and showed a binding activity of 40.9\%. Cold $\mathrm{PGI}_{2}\left(10^{-2} \mathrm{M}\right)$ and buffer were added to aliquots two and three, respectively, and after an additional 3-min incubation, they were chromatographed. The binding activity 
in the aliquot containing cold $\mathrm{PGI}_{2}$ was $7.5 \%$ while the activity in the buffered aliquot was $34.1 \%$.

The binding of $\mathrm{PGI}_{2}$ by serum was linear with increasing ${ }^{3} \mathrm{H}_{\mathrm{PGI}}$ at all concentrations tested (maximum, $200 \mathrm{nM}$ of $\left[{ }^{3} \mathrm{H}_{\mathrm{PGI}}\right.$ ) (Fig. $2 \mathrm{~A}$ ). Since saturation of serum binding with labeled $\mathrm{PGI}_{2}$ was impractical, two alternative approaches were taken to estimate the $\mathbf{P G I}_{2}$ concentration necessary to saturate serum binding. First, increasing concentrations (up to $10 \mathrm{mM}$ ) of unlabeled $\mathrm{PGI}_{2}$ were incubated in the serum with a standard concentration of $\left[{ }^{3} \mathrm{H}\right] \mathrm{PGI}_{2}$ and the reduction in the percentage of bound $\left[{ }^{3} \mathrm{H}\right] \mathrm{PGI}_{2}$ as a result of $\mathrm{PGI}_{2}$ displacement was determined (Fig. $2 \mathrm{~B}$ ). Reduction in the binding began to be noted at $0.5 \mathrm{mM} \mathrm{PGI}$ and a hyperbolic dose-response curve was obtained. The second approach was to add increasing concentrations of unlabeled $\mathrm{PGI}_{2}$ to the serum and to measure the $6 \mathrm{KPGF}_{1 \alpha}$ content to peak I (Fig. 2 B). A similar doseresponse curve was observed.

The $\mathbf{P G I}_{2}$ binding of three TTP sera was examined and a reduced first peak was found in each (Fig. $3 A$ ). The percentage of total $\left[{ }^{3} \mathrm{H}\right] \mathrm{PGI}_{2}$ in peak I was significantly lower in TTP sera (22.1 \pm SD, $4.4 \%)$ when compared with that of normal sera obtained from 19 age- and sex-matched donors (42.2 $\pm 6.2 \%)$. The $\mathrm{PGI}_{2}$ binding was measured multiple times on two different sera from each TTP patient (except T.G.). There was little variation in the binding values. The mean value of each TTP serum was W.J. $24.4 \% \pm \mathrm{SD}, 0.3$; T.G. $17.1 \%$, and H.S. $24.9 \% \pm 0.3$.

The effect of protein binding upon the $\mathrm{PGI}_{2}$ degradation rate was studied by assessment of antiaggregatory activity and ${ }_{6} \mathrm{KPGF}_{1 \alpha}$ content in peak I and peak II serum fractions. The antiaggregatory activity of protein-bound $\mathrm{PGI}_{2}$ decreased at

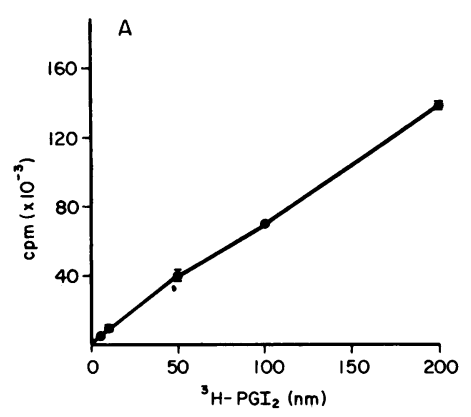

Figure 2. Dose-response curves of normal serum $\mathrm{PGI}_{2}$ binding $(A)$ Increasing concentrations of $\left[{ }^{3} \mathrm{H}_{\mathrm{PGI}} \mathrm{P}_{2}\right.$ were added to normal serum and applied to a Sephadex G-25 column. Percentages of total radioactivity present in peak I were calculated for each concentration. A linear curve was noted even at $200 \mathrm{nM}$ $\left[{ }^{3} \mathrm{H}_{\mathrm{PGI}}\right.$. (B) Increasing concentrations of unlabeled authentic $\mathrm{PGI}_{2}$ were incubated in serum with $16 \mathrm{nM}$ of $\left[{ }^{3} \mathrm{H}\right] \mathrm{PGI}_{2}$ and the percentages of total radioactivity present in peak I were determined and plotted against the unlabeled $\mathrm{PGI}_{2}$ concentration $(\bullet-\bullet)$. A hyperbolic reduction (displacement of peak I radioactivity was observed. Each value represents the mean of two experiments. In par-

allel experiments, increasing concentrations of unlabeled $\mathbf{P G I}_{2}$ were added to serum and the $6 \mathrm{KPGF}_{1 \alpha}$ content $(\square-\square)$ in peak $I$ measured by radioimmunoassay and plotted against the $\mathrm{PGI}_{2}$ concentration. A hyperbolic binding curve (similar to that obtained for the displacement) was obtained.

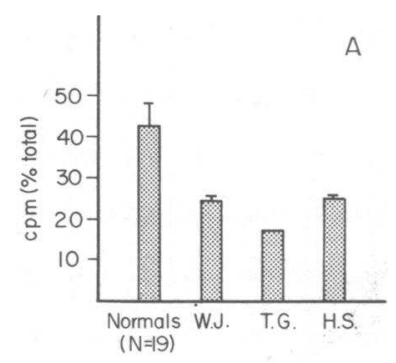

Figure 3. $\mathrm{PGI}_{2}$ binding and degradation in TTP. $(A)$ Comparison of $\mathrm{PGI}_{2}$ binding percentage between normal subjects and three TTP patients. The error bar of normal subjects represents the mean $\pm S D$ of 19 normal subjects. The bar of W.J. represents the mean \pm SD of five determinations of two separate serum samples; the bar of H.S. the mean \pm SD of three deter-

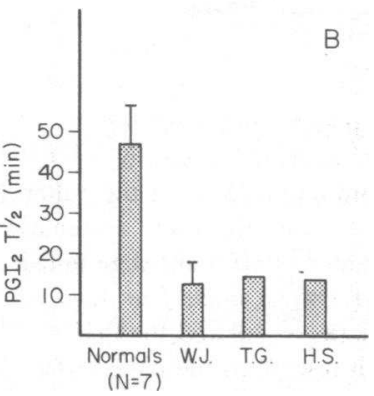
minations of two separate samples; and the bar of T.G. the mean of two determinations of a single sample. $(B) \mathrm{PGI}_{2}$ half-life $\left(t \frac{1}{2}\right)$ of normal subjects and patients. The error bar of normal subjects represents the mean $\pm \mathrm{SD}$ of seven normal subjects, whereas the W.J. bar represents the mean $\pm S D$ of five determinations of two separate serum samples.

The bars of H.S. and T.G. represent a mean value of two determinations.

slower rate than the activity of unbound $\mathrm{PGI}_{2}$ (Fig. 4). In 10 normal sera, there were positive correlations between the $\mathrm{PGI}_{2}$ binding, $\mathrm{PGI}_{2}$ antiaggregatory activity and $6 \mathrm{KPGF}_{1 \alpha}$ content in peak I (Table I). The antiaggregatory activity and $6 \mathrm{KPGF}_{1 \alpha}$ content of peak I of TTP serum (W.J.) were proportionally reduced when compared with normals.

To confirm that defective binding leads to accelerated $\mathbf{P G I}_{2}$ degradation, $\mathrm{PGI}_{2}$ was added to normal and TTP sera, and the half-life of $\mathbf{P G I}_{2}$ was determined. The $\mathbf{P G I}_{2}$ half-life was

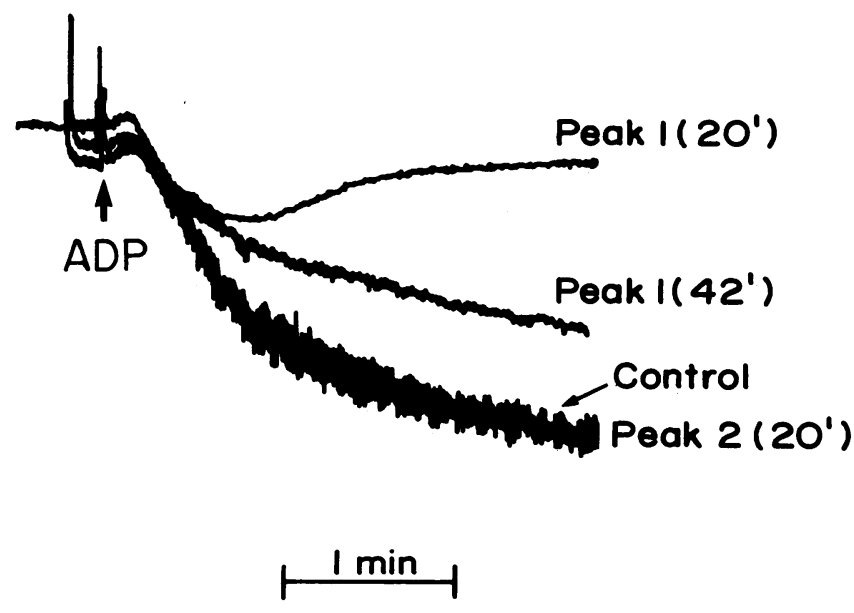

Figure 4. Inhibition of ADP-induced platelet aggregation by the two representative peaks collected from Sephadex G-25 gel filtration. The tracings show changes in light transmission in an aggregometer. $30 \mu \mathrm{l}$ of fractions representing peak I or peak II were added to $0.5 \mathrm{ml}$ human PRP $\left(3 \times 10^{8}\right.$ platelets $\left./ \mathrm{ml}\right)$ at $37^{\circ} \mathrm{C}$ for $1 \mathrm{~min}$ before ADP $(3$ $\mu \mathrm{M})$ was added. Peak I exhibited a potent anti-aggregatory activity when it was eluted from the column $(\sim 20 \mathrm{~min}$ after it was applied to the column). Furthermore, it retained antiaggregatory activity up to $\mathbf{4 2} \mathrm{min}$ after its addition to the column. Peak II, similar to $\mathbf{P G I}_{2}$ chromatographed in the absence of serum, had no anti-aggregatory activity. 
Table I. Comparison of $\mathrm{PGI}_{2}$ Binding with $\mathrm{PGI}_{2}$ Anti-aggregatory Activity and $6 \mathrm{KPGF}{ }_{1 \alpha}$ Content in Gel Filtration

\begin{tabular}{|c|c|c|c|c|c|c|c|c|c|c|c|c|}
\hline \multirow{3}{*}{ Subjects } & \multicolumn{6}{|l|}{ Peak I } & \multicolumn{6}{|l|}{ Peak II } \\
\hline & \multicolumn{2}{|c|}{$\mathrm{PGI}_{2}$ radioactivity } & \multicolumn{2}{|c|}{$\begin{array}{l}\mathrm{PGI}_{2} \\
\text { activity }\end{array}$} & \multicolumn{2}{|c|}{$\begin{array}{l}\text { 6KPGF } \text { Ia }_{\text {content }} \\
\text { col }\end{array}$} & \multicolumn{2}{|c|}{$\mathrm{PGI}_{2}$ radioactivity } & \multicolumn{2}{|c|}{$\begin{array}{l}\mathbf{P G I}_{2} \\
\text { activity }\end{array}$} & \multicolumn{2}{|c|}{$\begin{array}{l}\text { 6KPGF } 1 \text { la } \\
\text { content }\end{array}$} \\
\hline & $\mathrm{cpm}\left(\times 10^{3}\right)$ & $\%$ & $n g$ & $\%$ & $n g$ & $\%$ & $\operatorname{cpm}\left(\times 10^{3}\right)$ & $\%$ & $n g$ & $\%$ & $n g$ & $\%$ \\
\hline W.J. & 8.1 & 23.4 & 260 & 21.9 & 300 & 25.3 & 26.5 & 76.6 & 0 & 0 & 883 & 74.7 \\
\hline A normal serum & 13.9 & 41.5 & 518 & 43.9 & 542 & 40.7 & 19.6 & 58.5 & 0 & 0 & 790 & 59.3 \\
\hline \multicolumn{13}{|l|}{$\begin{array}{l}\text { Pooled normal } \\
\text { serum }\end{array}$} \\
\hline$(n=10)$ & 15.2 & 44.7 & 518 & 43.9 & 539 & 43.8 & 18.8 & 55.3 & 0 & 0 & 692 & 56.2 \\
\hline
\end{tabular}

$10 \mathrm{nM}$ of $\left[{ }^{3} \mathrm{H}_{\mathrm{PGI}}\right.$ and $10 \mu \mathrm{M}$ of $\mathrm{PGI}_{2}$ sodium were added to serum for $3 \mathrm{~min}$ and applied to a Sephadex G-25 column. Fractions representing peak I and peak II were collected. The radioactivity, $\mathrm{PGI}_{2}$ antiaggregatory activity and $6 \mathrm{KPGF}_{1 \alpha}$ in both peaks were determined.

significantly shortened in all three TTP sera (Fig. $3 \mathrm{~B}$ ). To determine the specificity of the binding abnormality, serum binding of $\left[{ }^{14} \mathrm{C}\right]$ arachidonic acid, $\left[{ }^{3} \mathrm{H}\right] \mathrm{PGE}_{1}$ and $\left[{ }^{3} \mathrm{H}\right] 6 \mathrm{KPGF}_{1 \alpha}$ was compared in normal and TTP sera. Serum PGE $_{1}$ binding appeared to be reduced in W.J. and T.G. but was normal in H.S. (Fig. 5). On the other hand, there was no difference in arachidonic acid or $6 \mathrm{KPGF}_{1 \alpha}$ binding between the TTP and the normal sera.

Mixing experiments. Since plasma replacement was beneficial in all three patients, we examined the in vitro and in vivo effects of serum or plasma on $\mathbf{P G I}_{2}$ binding and stability. The addition of normal serum to TTP sera significantly increased $\mathrm{PGI}_{2}$ binding and half-life (Table II). T.G. and H.S. seemed to have a greater response to a 50:50 mixture of their sera with normal sera than W.J., suggesting that the defects might differ between W.J. and the other two (T.G. and H.S.). The in vivo effect in two patients (H.S. and W.J.) following infusion of $3 \mathrm{U}$ of fresh frozen plasma was investigated. Despite similar clinical benefit, the effect of plasma upon $\mathrm{PGI}_{2}$ binding was quite dissimilar in these two patients. In H.S. there was an immediate rise of $\mathbf{P G I}_{2}$ binding followed by a slow decline over $35 \mathrm{~d}$ (Fig. 6). By contrast, improvement in the $\mathrm{PGI}_{2}$ binding of W.J.'s serum was delayed and the level of elevation was suboptimal when compared with that of H.S. These data provide further evidence to suggest that more than one defect in $\mathrm{PGI}_{2}$ binding might exist in these two patients.
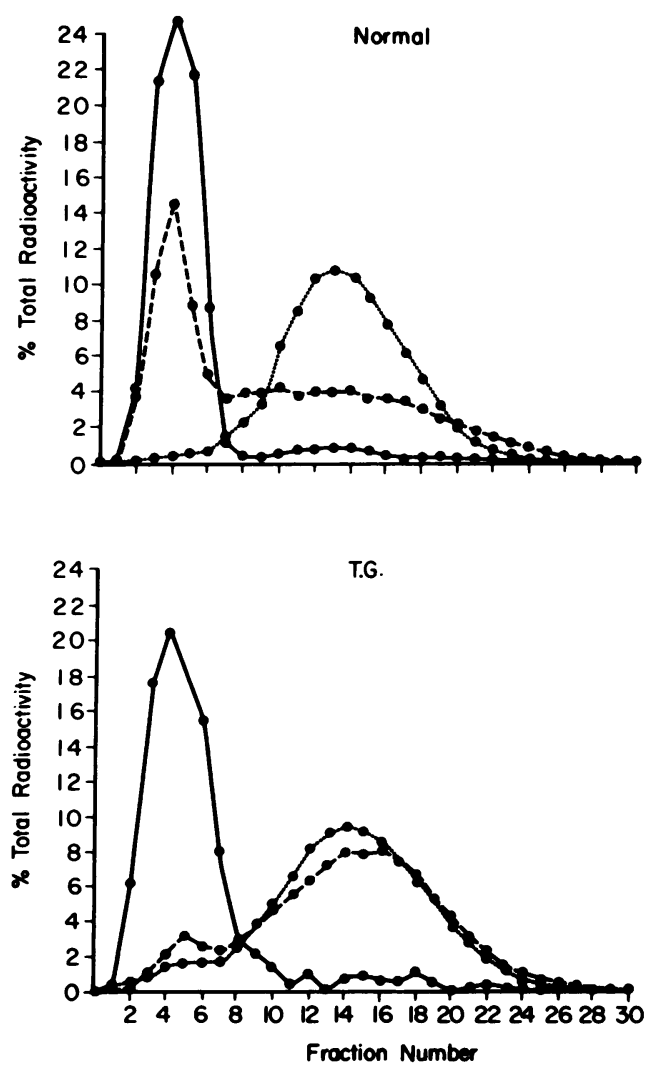
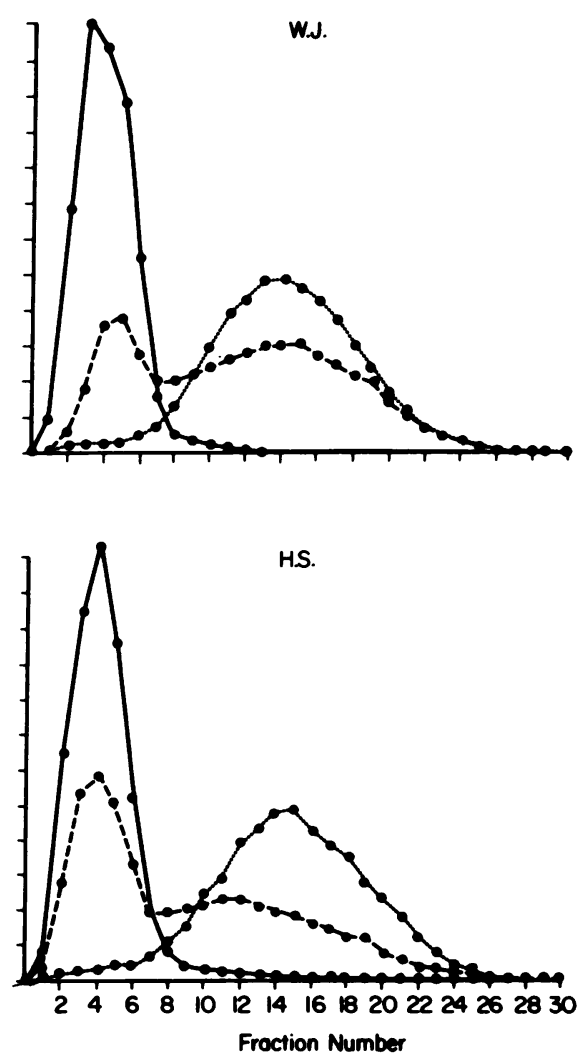

Figure 5. Comparison of the serum binding of $\left[{ }^{14} \mathrm{C}\right]$ arachidonic acid $(\bullet-\bullet),\left[{ }^{3} \mathrm{H}\right] \mathrm{PGE}_{1}(\bullet---\bullet)$ and $\left[{ }^{3} \mathrm{H}\right] 6 \mathrm{KPGF}_{1 \alpha}(\bullet \cdots \bullet)$ between a normal subject and three patients. None of the sera bound $6 \mathrm{KPGF}_{1 \alpha}$. The percentage of $P E_{1}$ binding was reduced in W.J. (28.8\%) and T.G. (11.0\%) but was normal in H.S. (50.3\%) when compared with a normal subject $(46.5 \%)$. There was no difference in $\left[{ }^{14} \mathrm{C}\right]$ arachidonic acid binding between the normal and any of the patients. 
Table II. Correction of Abnormal PGI Binding and Degradation by Normal Serum

\begin{tabular}{|c|c|c|c|c|c|c|c|}
\hline \multirow{2}{*}{$\begin{array}{l}\text { Patient } \\
\text { serum }\end{array}$} & \multirow{2}{*}{$\begin{array}{l}\text { Normal } \\
\text { serum }\end{array}$} & \multicolumn{3}{|c|}{$\mathrm{PGI}_{2}$ binding } & \multicolumn{3}{|c|}{$\mathrm{PGI}_{2} t_{1 / 2}$} \\
\hline & & W.J. & T.G. & H.S. & W.J. & T.G. & H.S. \\
\hline vol \% & vol \% & $\%$ & $\%$ & $\%$ & $\min$ & $\min$ & $\min$ \\
\hline 100 & 0 & 24.5 & 17.0 & 24.0 & 17 & 15 & 14 \\
\hline 75 & 25 & 34.0 & & & & & \\
\hline 50 & 50 & 34.5 & 33.1 & 37.9 & 30 & 38 & 30 \\
\hline 25 & 75 & 38.6 & & & & & \\
\hline 0 & 100 & 44.9 & 40.6 & 40.6 & 43 & 43 & 43 \\
\hline
\end{tabular}

Various volumes of patient and normal sera were mixed and incubated at $37^{\circ} \mathrm{C}$ for $30 \mathrm{~min}$. $0.35 \mathrm{ml}$ of the mixture was removed and added to $\left[{ }^{3} \mathrm{H}_{\mathrm{PGI}}(10\right.$ $\mathrm{nM}$ ) at $22^{\circ} \mathrm{C}$ for $3 \mathrm{~min}$ and the percentage of binding was measured. In parallel experiments, unlabeled $\mathrm{PGl}_{2}$ sodium was added to the serum mixture and the half-life $\left(t_{1 / 2}\right)$ of $\mathrm{PGI}_{2}$ activity was determined by bioassay.

To evaluate this possibility, equal volumes of serum from W.J. and H.S. were mixed and the $\mathrm{PGI}_{2}$ binding capacity of the mixture was compared that of the individual serum. The percentage of binding in the mixture was $33.3 \%$, significantly higher than either of the individual values (W.J. 24.8\%, H.S. 24\%).

Since serum albumin has been implicated in prolonging $\mathrm{PGI}_{2}$ activity (12-15), we investigated the effect of several albumin preparations on serum $\mathbf{P G I}_{2}$ binding in W.J. and H.S. sera (Table III). When used alone, Cohn fraction V albumin preparations did not bind $\mathbf{P G I}_{2}$, crystalline albumin bound only a small percentage of $\mathrm{PGI}_{2}$, while defatted albumin bound a quantity of $\mathbf{P G I}_{2}$ equivalent to that bound by serum. When these albumin preparations were added in physiologic concentrations $(40 \mathrm{mg} / \mathrm{ml})$ to W.J. and H.S. sera, the following results were obtained. Cohn fraction $\mathrm{V}$ did not influence the $\mathrm{PGI}_{2}$ binding in H.S. but suppressed the binding in W.J. Crystalline albumin increased the $\mathrm{PGI}_{2}$ binding in both patients. Defatted albumin elicited an additive response in $\mathrm{PGI}_{2}$ binding in H.S. serum, but no effect in W.J. serum (Table III).

Characterization of binding defects in TTP sera. For the reason that TTP sera appear to be deficient in components that normally prevent rapid $\mathrm{PGI}_{2}$ hydrolysis and hence increase $\mathrm{PGI}_{2}$ bioavailability, normal serum was studied to identify these protective components. When normal serum was treated

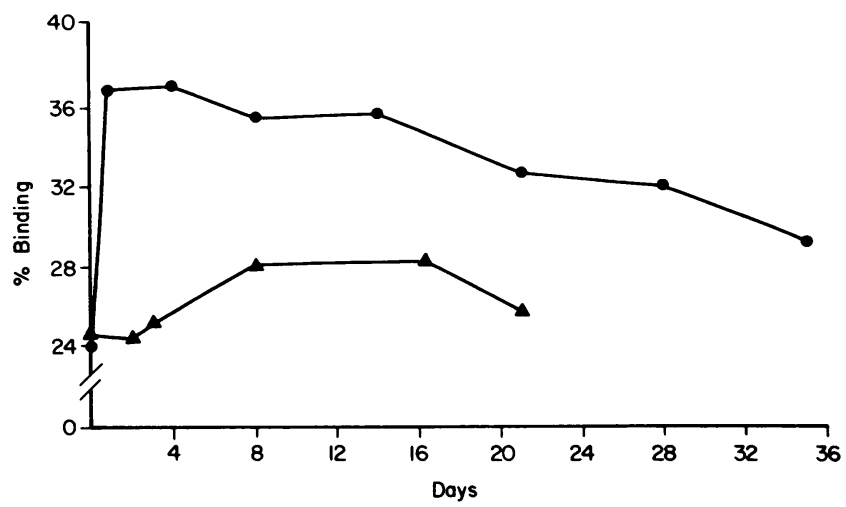

Figure 6. Responses of serum $\mathrm{PGI}_{2}$ binding to transfusions of $3 \mathrm{U}$ of

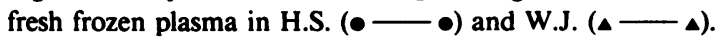

Table III. Binding of $\mathrm{PGI}_{2}$ by Several Albumin Preparations and Their Effects on Defective PGI ${ }_{2}$ Binding in TTP Patients

\begin{tabular}{|c|c|c|c|c|c|}
\hline \multirow[b]{3}{*}{$\begin{array}{l}\text { Albumin } \\
\text { preparations }\end{array}$} & \multirow{3}{*}{$\begin{array}{l}\text { Albumin } \\
\text { alone }\end{array}$} & \multicolumn{4}{|c|}{$\mathrm{PGI}_{2}$ binding } \\
\hline & & \multicolumn{2}{|l|}{ W.J. } & \multicolumn{2}{|l|}{ H.S. } \\
\hline & & $\bar{c}$ alb. & $\overline{\mathbf{s}}$ alb. & $\overline{\mathbf{c}}$ alb. & $\overline{\mathbf{s}}$ alb. \\
\hline & $\%$ & \% & $\%$ & $\%$ & $\%$ \\
\hline Cohn fraction $\mathbf{V}$ & $<1.0$ & 11.7 & 24.5 & 31.4 & 24.0 \\
\hline Crystalline albumin & 4.3 & 31.3 & 24.5 & 41.4 & 24.0 \\
\hline Defatted albumin & 53.6 & 53.3 & 24.5 & 70.3 & 24.0 \\
\hline
\end{tabular}

$\left[{ }^{3} \mathrm{H}_{\mathrm{PGI}}(10 \mathrm{nM})\right.$ was added to the albumin preparation $(40 \mathrm{mg} / \mathrm{ml})$ at $22^{\circ} \mathrm{C}$ for $3 \mathrm{~min}$ and applied to a Sephadex G-25 column. Percentage of total radioactivity present in peak I was calculated. In the mixing experiments, albumin was added to serum and the percentage of radioactivity in peak I determined. $\bar{c}$ alb. denotes that $\mathbf{4 0} \mathrm{mg}$ albumin was added and $\overline{\mathrm{s}}$ alb. denotes that no albumin was added. Each value represents a mean of two experiments with a variability of $<5 \%$.

with $30,60,70$, and $80 \%$ saturated $\left(\mathrm{NH}_{4}\right)_{2} \mathrm{SO}_{4}$, the binding activity was recovered only in the supernatant of the $60 \%$ $\left(\mathrm{NH}_{4}\right)_{2} \mathrm{SO}_{4}$ solution (fraction $\mathrm{D}$ ). In the process, the specific binding activity was raised from $1.51 \pm \mathrm{SD}, 0.22 \% / \mathrm{mg}$ protein (serum, $n=10$ ) to $2.78 \pm 0.70 \% / \mathrm{mg}$ protein (fraction $\mathrm{D}, n$ $=10$ ). The binding activity of W.J. and H.S. sera was also located in the $60 \%\left(\mathrm{NH}_{4}\right)_{2} \mathrm{SO}_{4}$ supernatant and this fractionation process produced an increase in specific $\mathbf{P G I}_{2}$ binding activity that was proportional to the increase observed with normal serum. Normal fraction D corrected the $\mathbf{P G I}_{2}$ binding of W.J. and H.S. serum (Table IV).

The binding components in fraction $\mathrm{D}$ were nondialyzable. The binding activities were completely eliminated by trypsin ( $1 \mathrm{mg} / \mathrm{ml})$, chymotrypsin $(1 \mathrm{mg} / \mathrm{ml})$, and by boiling for $3 \mathrm{~min}$. Neither heating the serum at $56^{\circ} \mathrm{C}$ for $30 \mathrm{~min}$ nor exposure to neuraminidase had an effect on binding activity. Further experiments were initiated to isolate the binding proteins. When fraction D was mixed with hydroxylapatite, $85 \%$ of the applied protein was unadsorbed and the remaining $15 \%$ could be eluted with $1.0 \mathrm{M}$ sodium phosphate buffer at $\mathrm{pH}$ 8.5. However, despite a virtually complete recovery of the applied protein, binding activity was undetectable in either fraction (Table V). Similar loss of binding activity despite good protein recovery was observed with dye ligand chromatography. It is of particular interest to note that despite the fact that $97 \%$ of the applied protein was unadsorbed to Orange $A$ and the remaining $3 \%$ was completely eluted, there was no significant binding activity in the unadsorbed or the eluted samples.

Table IV. Effect of Serum Fraction D on Patient's PGI ${ }_{2}$ Binding and Degradation

\begin{tabular}{|c|c|c|c|c|c|c|c|}
\hline \multirow{2}{*}{$\begin{array}{l}\text { Patient } \\
\text { serum }\end{array}$} & \multirow{2}{*}{$\begin{array}{l}\text { Fraction } \\
\text { D }\end{array}$} & \multicolumn{3}{|c|}{$\mathrm{PGI}_{2}$ binding } & \multicolumn{3}{|c|}{$\mathrm{PGI}_{2} t_{1 / 2}$} \\
\hline & & W.J. & T.G. & H.S. & W.J. & T.G. & H.S. \\
\hline vol. \% & vol. $\%$ & $\%$ & $\%$ & $\%$ & $\min$ & $\min$ & $\min$ \\
\hline 100 & 0 & 24.5 & 17.0 & 24.0 & 17 & 15 & 14 \\
\hline 50 & 50 & 33.4 & 39.5 & 37.7 & 55 & 37 & 95 \\
\hline 0 & 100 & 51.6 & 51.6 & 51.6 & 150 & 150 & 150 \\
\hline
\end{tabular}


Table V. Summary of Chromatographic Purification of Fraction $D^{*}$

\begin{tabular}{|c|c|c|c|c|c|c|}
\hline \multirow[b]{2}{*}{ Chromatography } & \multicolumn{3}{|c|}{ Nonadsorbed fraction } & \multicolumn{3}{|c|}{ Eluted fraction } \\
\hline & Protein & Albumin & Binding activity & Protein & Albumin & Binding activity \\
\hline & $\%$ & \% & \% & $\%$ & $\%$ & $\%$ \\
\hline Hydroxylapatite & 85 & NT $\ddagger$ & $<5$ & 15 & NT & $<5$ \\
\hline Green A & 11 & 8 & $<5$ & 89 & 86 & $<5$ \\
\hline Red A & 49 & 34 & $<5$ & 51 & 47 & $<5$ \\
\hline Orange A & 97 & 83 & $<5$ & 3 & 0 & $<5$ \\
\hline Blue A & 9 & 5 & $<5$ & 58 & 55 & $<5$ \\
\hline DEAE(DE-52) & 69 & NT & 10.8 & 31 & NT & $<5$ \\
\hline
\end{tabular}

* See text for details. $¥ N T$, Not tested.

When fraction D (specific binding activity $3.1 \% / \mathrm{mg}$ protein) was applied to a DEAE-Sephacel column equilibrated in $\mathbf{5 0}$ mM sodium phosphate buffer, $\mathrm{pH} 7.0,69 \%$ of the protein passed through the column unadsorbed. However, most of the activity was lost and the specific binding activity of the unadsorbed portion was reduced to $1.8 \% / \mathrm{mg}$ of protein. The protein that bound to the column was eluted with $1 \mathrm{M} \mathrm{NaCl}$. The eluted portion by itself had no binding activity; however, when it was mixed with the unadsorbed protein, the binding activity of the mixture was greater than either one of the individual fractions and approached that of fraction $D$, i.e., $2.9 \% / \mathrm{mg}$ of protein.

Three major protein bands with pl's of 5.0, 5.2, and 5.6 were consistently noted when normal fraction $\mathrm{D}(n=10)$ and TTP fraction D (W.J. and H.S.) were isoelectrofocused. There was no apparent difference between the normal and TTP fraction $\mathrm{D}$. Three distinct bands were also noted when normal and TTP fraction D were applied to SDS-PAGE; a heavily stained band (estimated molecular weight of 67,000) and two minor bands (80,000 and 45,000 mol wt, respectively). Again, there was no apparent difference between normal and TTP fraction D. Preparative electrofocusing over a $\mathrm{pH}$ range of 4.0-8.0 was used to subdivide fraction $D$ into four $\mathrm{pH}$ zones (i.e., pH 4.0-5.1, 5.1-5.3, 5.3-5.7, and 5.7-8.0). Each of the first three zones contained a major protein band. No single pH zone exhibited active binding activity; however, when all four zones were recombined and tested, binding activity could be partially recovered (i.e., $42-81 \%$ of the initial binding activity) in 3 of 10 experiments. In the three experiments with partial recovery of the activity, the binding activity was primarily found in a mixture of the $\mathrm{pH}$ zones between 5.1 and 5.7.

As TTP sera contained erythrocyte and platelet fragments that might bind $\mathrm{PGI}_{2}$, normal sera $(n=3)$ and two TTP sera (W.J. and H.S.), were ultracentrifuged at $103,000 \mathrm{~g}$ for $1 \mathrm{~h}$ to remove cell fragments and the supernatant was tested for $\mathbf{P G I}_{2}$ binding. There was no difference between the uncentrifuged and the ultracentrifuged samples. To determine whether TTP samples contained platelet aggregating activity as described by Lian et al. (2), we added TTP PPP or heated serum $\left(56^{\circ} \mathrm{C}\right.$ for $30 \mathrm{~min}$ ) to washed normal platelet suspensions and measured platelet aggregation in an aggregometer. None of our TTP samples exhibited platelet aggregating activity.

\section{Discussion}

This study indicates that human serum binds $\mathbf{P G I}_{2}$. The binding occurs rapidly and is readily reversible. The components responsible for the binding property are serum proteins that are soluble in $60 \%$ saturated $\left(\mathrm{NH}_{4}\right)_{2} \mathrm{SO}_{4}$. Further efforts to purify the protein(s) were hampered by an accompanying loss of binding activity. Reasons for this loss of activity could include protein instability or its presence in only trace amounts. An alternative explanation could be that $\mathrm{PGI}_{2}$ binding may require the association of two components that are dissociated by purification procedures. The latter is supported by the observation that the binding activity lost after ion-exchange chromatography or preparatory isoelectrofocusing was recovered when their respective fractions were recombined. This hypothesis is further supported by the demonstration of two types of mutually correctable binding defects in chronic TTP.

The binding, half-life, and antiaggregatory activity of $\mathrm{PGI}_{2}$ is markedly reduced in TTP serum as compared with normal serum. The association of diminished binding with diminished half-life and antiaggregatory effect suggests that $\mathrm{PGI}_{2}$ binding may protect $\mathrm{PGI}_{2}$ from degradation and modulate the delivery of $\mathbf{P G I}_{2}$ to damaged vascular sites and thus provide a control over platelet aggregate formation. Diminished $\mathrm{PGI}_{2}$ binding in TTP might therefore be an important determinant for the disseminated platelet aggregatory phenomena observed in TTP.

It is interesting to note that two TTP sera (W.J. and H.S.) with a clearly demonstrable impairment in $\mathrm{PGI}_{2}$ binding were mutually corrective when mixed. The addition of normal serum, normal fraction D, or H.S. serum achieved a significant correction of the $\mathbf{P G I}_{2}$ binding defect in W.J. serum. Similarly, the binding defect in H.S. was corrected by normal serum, normal fraction $D$, or W.J. serum. These findings indicate that the binding defects in W.J. and H.S. are different. Although plasma transfusions were efficacious in both patients, the response of $\mathrm{PGI}_{2}$ binding to in vivo infusion of plasma was also quite different in these two patients. As compared to H.S., serum $\mathrm{PGI}_{2}$ binding in W.J. responded suboptimally to in vivo plasma infusion and to in vitro addition of albumin.

Although a uniform theory could not be afforded to explain these intriguing defects, we speculate that the defects may be due to a deficiency of the binding protein, on the one hand, and its cofactor, on the other. This hypothesis provides a rational explanation for mutual correctability as well as correction of both defects by normal serum and its derivative, fraction D. However, the lack of an appreciable increase in W.J.'s serum $\mathrm{PGI}_{2}$ binding after in vivo plasma infusion tends to mitigate against this hypothesis.

Serum albumin has been proposed as a $\mathbf{P G I}_{2}$ stabilizing factor. Dye ligand experiments (Table $\mathrm{V}$ ) and isoelectrofocusing experiments (albumin, pI 5.0) strongly suggest, however, that 
an albumin "deficiency" was not responsible for the impaired $\mathrm{PGI}_{2}$ binding observed in these two patients with TTP. This notion is further confirmed by the failure of several commercial human albumin preparations to increase $\mathbf{P G I}_{2}$ binding. Moreover, since the albumin levels in all three TTP sera were normal, the binding defects are unlikely due to albumin abnormalities.

The pathophysiologic significance of abnormal $\mathrm{PGI}_{2}$ binding and stability in TTP remains to be established. One may speculate that this abnormality may play an important role in predisposing patients to recurrent microangiopathy. Following vascular injury, $\mathrm{PGI}_{2}$ production may be stimulated $(16,17)$ and protein binding may be needed to protect $\mathrm{PGI}_{2}$ from rapid hydrolysis and catabolism (18). This may be critical to the bioavailability of $\mathbf{P G I}_{2}$ for dispersion of platelet aggregates and prevention of new aggregate formation. Diminished binding activity may thus compromise $\mathbf{P G I}_{2}$ bioavailability and lead to inadequate physiologic modulation of platelet thrombus formation at times of severe vascular insult. Further characterization of the binding proteins and their abnormalities in various vascular disorders must be pursued to advance our understanding of the pathophysiology and treatment of these important clinical problems.

\section{Acknowledgments}

The authors wish to thank Dr. D. Williams for providing T.G. serum; Dr. Udo Axen and Dr. John Pike of the Upjohn Co. for the generous supply of $\mathrm{PGI}_{2}$ and $6 \mathrm{KPGF}_{1 \alpha}$; and $\mathrm{Ms}$. Molyneux for secretarial assistance.

This work was supported in part by a program project grant from the National Institutes of Health (P01-NS-18494) and a grant from the Chicago Heart Association (81-10).

\section{References}

1. Amorosi, E. L., and J. E. Ultmann. 1966. Thrombotic thrombocytopenic purpura: report of 16 cases and review of the literature. Medicine (Baltimore). 45:139-159.

2. Lian, E. C.-Y., D. R. Harkness, J. J. Byrnes, H. Wallach, and R. Nunez. 1979. Presence of a platelet aggregating factor in the plasma of patients with TTP and its inhibition by normal plasma. Blood. 53:333-337.

3. Moake, J. L., C. K. Rudy, J. H. Troll, M. J. Weinstein, N. M
Colannino, J. Azocar, R. H. Seder, S. L. Hong, and D. Deykin. 1982. Unusually large plasma Factor VIII:von Willebrand factor multimers in chronic relapsing TTP. N. Engl. J. Med. 307:1432-1435.

4. Chen, Y-C, B. McLeod, E. R. Hall, and K. Wu. 1981. Accelerated prostacyclin degradation in thrombotic thrombocytopenic purpura. Lancet. II:267-269.

5. Wu, K. K., E. R. Hall, and A. Papp. 1982. Prostacyclin stabilizing factor deficiency in thrombotic thrombocytopenic purpura. Lancet. I: 460-461.

6. Rossi, E. C., F. del Greco, H. C. Kwann, and B. Lerman. 1980. Hemodialysis-exchange transfusion for treatment of thrombotic thrombocytopenic purpura. JAMA. (J. Am. Med. Assoc.). 244:14661468.

7. Hsi, R. S. P., W. T. Stoelle, J. P. McGrath, and D. R. Morton. 1980. Tritium labeled prostacyclin sodium salt. J. Labeled Compound and Radiopharm. 18:1437-1447.

8. Acred, P., D. M. Brown, T. L. Hardy, and K. R. L. Mansford. 1963. A new approach to studying the protein-binding properties of penicillins. Nature (Lond.). 199:758-759.

9. Born, G. V. R. 1962. Aggregation of blood platelets by adenosine diphosphate and its reversal. Nature (Lond.). 194:927-929.

10. Lowry, O. H., N. J. Rosebrough, A. L. Farr, and R. J. Randall. 1951. Protein measurement with the Folin phenol reagent. J. Biol. Chem. 193:261-275.

11. Laemmli, U. K. 1970. Cleavage of structural proteins during the assembly of the head of bacteriophage $T_{4}$. Nature (Lond.). 227:680685.

12. Wynalda, M. A., and F. A. Fitzpatrick. 1980. Albumin stabilizes prostaglandin $\mathrm{I}_{2}$. Prostaglandins. 20:853-861.

13. Orchard, M. A., and C. Robinson. 1981. Stability of prostacyclin in human plasma and whole blood. Studies on the protective effect of albumin. Thromb. Haemostasis. 46:645-647.

14. Pifer, D. D., G. L. M. Cagan, and C. M. Chesney. 1981. Stability of $\mathbf{P G I}_{2}$ in human blood. Prostaglandins. 21:165-175.

15. Gimeno, M. F., L. Sterlin-Borda, E. S. Borda, M. A. Lazzari, and A. L. Gimeno. 1980. Human plasma transforms $\mathbf{P G I}_{2}$ into a platelet antiaggregatory substance which contracts isolated bovine coronary arteries. Prostaglandins. 19:907-916.

16. Weksler, B. B., C. W. Ley, and E. A. Jaffe. 1978. Stimulation of endothelial cell prostacyclin production by thrombin, trypsin and ionophore A23187. J. Clin. Invest. 62:923-930.

17. MacIntyre, D. E., J. D. Pearson, and J. L. Gordon. 1978. Localization and stimulation of prostacyclin production in vascular cells. Nature (Lond.). 271:549-551.

18. Rosenkranz, B., C. Frischer, K. E. Weimer, and J. C. Frolich. 1980. Metabolism of prostacyclin and 6-keto-PGF ${ }_{1 \alpha}$ in man. J. Biol. Chem. 255:10194-10198. 